\title{
Drying Effect for Amino Acid Composition of Worms Lawar Perinereis cf.cultrifera (BLEEKER 1840) Wearlilir Waters from Kei Islands Maluku Southeast District
}

\author{
Martha Rettob* ${ }^{1}$, Cenny Putnarubun ${ }^{2}$, Nally Erbabley ${ }^{1}$, Santy Rahantoknam ${ }^{1}$ \\ ${ }^{I}$ Fishery Cultivation Technology, Politeknik Perikanan Negeri Tual, Maluku, Indonesia \\ ${ }^{2}$ Fishing Product Technology, Politeknik Perikanan Negeri Tual, Maluku, Indonesia \\ Corresponding author:* martharettob@gmail.com
}

\begin{abstract}
The purpose of this study was to determine the effect of drying on the amino acid composition of the worm lawar Perinereis cf.cultrifera (Bleeker 1840) The method used is a natural drying process with artificial sun with electric oven and then analyzed the amino acid composition by GC (Gas Kromotofrafi). Result obtained for the solar drying process there are 14 types of amino acids with the composition: 0.890 $\mathrm{mg} / \mathrm{g} 0.746 \mathrm{mg} / \mathrm{g}$ Alanine, $0.096 \mathrm{mg} / \mathrm{g}$ Alphaamino Butyric acid, 2,090 mg/g Valine, 0.088 $\mathrm{mg} / \mathrm{g}$ amino Beta Isobutyric ACIC, threonine, $0.913 \mathrm{mg} / \mathrm{g}$ Aspartic acids, 16,505 mg/g Hydroxyproline, 15,361 mg/g Glutamic acid, $0.581 \mathrm{mg} / \mathrm{g}$ Phenylalanine, $2.254 \mathrm{mg} / \mathrm{g}$ Alphaaminoadipic acids, $0.868 \mathrm{mg} / \mathrm{g}$ Ornithine, 0.959 $\mathrm{mg} / \mathrm{g}$ Lysine, $1,209 \mathrm{mg} / \mathrm{g}$ histidine, $0.993 \mathrm{mg} / \mathrm{g}$ of tyrosine, while the artificial drying (oven) there are 12 types of amino acids which are: $0.673 \mathrm{mg} / \mathrm{g}$ Alanine, $0.046 \mathrm{mg} / \mathrm{g}$ Glysine, $0.0678 \mathrm{mg} / \mathrm{g}$ Alphaamino Butyric acid, $0.224 \mathrm{mg} / \mathrm{g}$ Valine, 2.803 $\mathrm{mg} / \mathrm{g}$ Threonine, $0.297 \mathrm{mg} / \mathrm{g}$ Serine, $0.068 \mathrm{mg} / \mathrm{g}$ Methionine, $22,015 \mathrm{mg} / \mathrm{g}$ Hydroxyproline, 1.282 $\mathrm{mg} / \mathrm{g}$ Phenylalanine, $0,782 \mathrm{mg} / \mathrm{g}$ Alphaaminoadipic acids, $0.952 \mathrm{mg} / \mathrm{g}$ Ornithine, Lysine 1,049 .
\end{abstract}

Keywords: effect, amino acid composition, Lawar, Perinereis cf.cultrifera, drying

\section{INTRODUCTION}

One potential alternative materials as feed additives is tanh worm because it contains high protein and amino acids complete. The chemical composition of earthworm Lumbricus rubellus flour was $65.63 \%$ protein content [1] as well as the amino acid proline approximately $15 \%$ of the total 62 amino acids [2], while the type of L. Terrestrial earthworms for flour containing $32.60 \%$ crude protein [3], excavatus Perionyx earthworm flour containing $57.2 \%$ crude protein and contains essential amino acids that is complete. [4] with the administration of earthworm powder (TCT) as a poultry feed proved to accelerate the growth of live weight, increase muscle tissue formation, and improve feed efficiency. [5] also reported the antimicrobial activity found in earthworms. Eisenia foetida earthworms have glikolipoprotein mixture of G90 and has inhibitory against Staphylococcus sp. higher than the antibiotic Gentamicin $10 \mathrm{mg}$ and $20 \mathrm{mg}$ Enrofloxacin.

Lawar worms Perinereis cf.cultrifera (Bleeker 1840) marine chemical composition $13 \%$ especially high protein [6], this can allow for amino acids that can be used as a source of fish feed. Amino acids are proteins that influence the heating process will provide value to the quality of the amino acid lawar worms. This study aims to look at the effect of heating on the chemical composition of the amino acids.

\subsection{Materials}

\section{EXPERIMENTAL}

The material used is a worm lawar Perinereis cf.cultrifera (Bleeker 1840).

\subsection{Methods}

The method used three stages: The first stage penggeringan: worm lawar Perinereis cf.cultrifera (Bleeker 1840) penggeringan sunlight and electric oven. 
The second phase: sample preparation, sample smoothing worms Perinereis cf.cultrifera The hird stage: analysis of amino acid composition by GC.

\section{RESULTS AND DISCUSSIONS}

\subsection{Kromotogram-GC Worms Lawar}

From the results obtained from the GC kromotogram show that type of amino acid that is owned by worms highest lawar Hydroxyproline is an amino acid $16.505 \mathrm{mg} / \mathrm{g}$ of sample, and glutamic acid $15.361 \mathrm{mg} / \mathrm{g}$ of sample using the direct method of drying by the sun (natural), whereas with penggeringan artificial electric oven is the highest amino acid Hydroxyproline 22. 015 $\mathrm{mg} / \mathrm{g}$ of sample and acid glutanicnya lost or absent due to the heating (Fig.1).

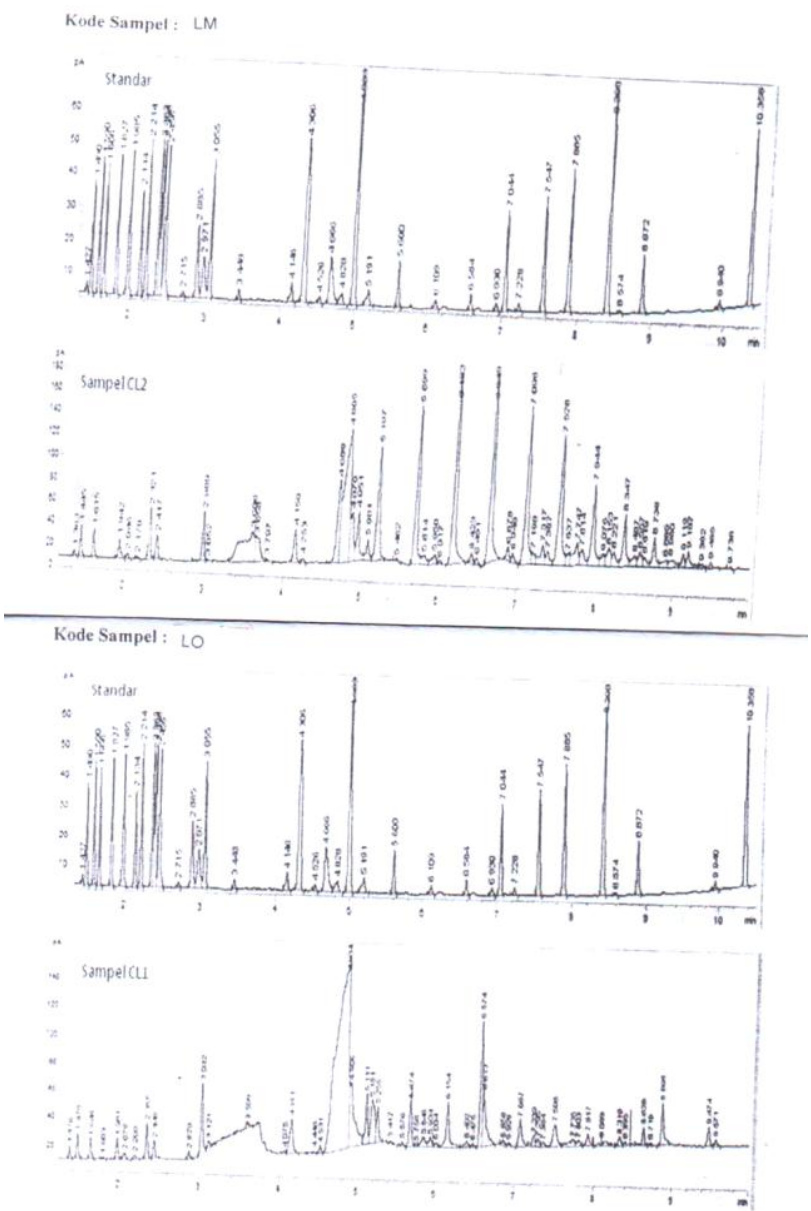

Fig.1. Lm : Kromatogram Lawar with drying sun Lo : Kromatogram Lawar with Oven Electric

\subsection{Amino Acid Composition}

Amino acids are needed by the children for future growth, is histidine and arginine. The process of drying in the sun has a histidine content of $1,209 \mathrm{mg} / \mathrm{g}$ sample, while the oven is not found penegringan histidine. Functions indispensable amino acids few examples of amino acids contained in the worm lawar feninalanin mmerupakan beginners and both of them form a

Table 3.1. Composition spesies amino acid worms lawar drying with sun

\begin{tabular}{|l|c|}
\hline \multicolumn{1}{|c|}{ Spesies amino acid } & $\begin{array}{c}\text { presentase } \\
\text { sampel) }\end{array}$ \\
\hline Alanine & 0,890 \\
Alpha Amino Butyric acid & 0,746 \\
Valine & 0,096 \\
Beta amino isobutyric acid & \\
Threonine & 2,090 \\
Aspartic acids & 0,088 \\
Hydroxyproline & 0,913 \\
Glutamic acid & 16,505 \\
Phenylalanine & 15,361 \\
Alpha-aminoadipic acids & 0,581 \\
Ornithine & 2,254 \\
Lysine & 0,868 \\
Histidine & 0,959 \\
tyrosine & 1,209 \\
& 0,993
\end{tabular}

Table 3.2. Composition spesies amino acid worms lawar drying sintetis with Oven electric

\begin{tabular}{|l|c|}
\hline \multicolumn{1}{|c|}{ Spesies amino acid } & $\begin{array}{c}\text { Presentase (mg/g } \\
\text { sampel) }\end{array}$ \\
\hline Alanine & 0,673 \\
Glysine & 0,046 \\
Alpha Amino Butyric acid & 0,678 \\
Valine & 0,224 \\
Threonine & 2,803 \\
Serine & 0,297 \\
Methionine & 0,068 \\
Hydroxyproline & 22,015 \\
Phenylalanine & 1,282 \\
Alpha-aminoadipic acids & 0,782 \\
Ornithine & 0,952 \\
Lysine & 1,049 \\
\hline \multicolumn{2}{|c}{} \\
\end{tabular}


tyrosine tyrosine and epinephrine, arginine, ornithine, citrulline, had a role in the synthesis of urea in the liver. [7]. Glycine can be fused with toxic substances and produce no toxic compounds and then excreted. Glycine also acts on synthetic porphyrin of hemoglobin and is also a constituent of glycolic acid. Essential histidine to histamine synthetic. Creatine is formed from arginine, glycine, and methionine, with phosphate to form creatine phosphate, glutamine and asparagine amino group which is cadanga respectively generated by glutamic acid and aspartic acid. All kinds of essential amino acids and non-essential both very important for the growth and development of children found available in full on the worm lawar Perinereis cf.cultrifera (Bleeker 1840) in the village of East Maluku Wearlilir.

\section{CONCLUSION}

The conclusion from this study is that there is:

1. Drying with sunlight there are 14 types of amino acids .

2. Electric Oven drying there are 12 types of amino acids.

\section{ACKNOWLEDGMENTS}

Big thank you to the Dit. Litabmas DiktiKemdikbud top seed funding grant research universities are given for funding this research

\section{REFERENCES}

[1] Damayanti, E., H. Julendra dan A. Sofyan. (2008). Aktivitas Antibakteri Tepung Cacing Tanah (Lumbricus rubellus) Dengan Metode Pembuatan yang Berbeda terhadap Escherichia coli . Prosiding Seminar Nasional Pangan Tahun 2008 : 54-60, 17 Januari 2008: PATPI.

[2] Cho, J.H., C.B. Park, Y.G. Yoon dan S.C. Kim. (1998). Lumbricin I, a Novel ProlineRich Antimicrobial Peptide from the Earthworm: Purification, cDNA Cloning and Molecular Characterization. Biochim. Biophys. Acta. 1408 (1): 67-76.

[3] Julendra, H. (2003). Uji Aktivitas Anti Bakteri dalam Cacing Tanah sebagai Bahan Pakan Ayam terhadap Pertumbuhan Bakteri Salmonella pul-lorum secara In-vitro. Prosiding Pemaparan Hasil Litbang IPT 2003.
[4] Tram, N.D.Q, L.D. Ngoan dan B. Ogle. (2005). Culturing Earthworms on Pig Manure and The Effect of Replacing Trash Fish by Earthworms on The Growth Performance of Catfish (Clarias macrocephalus $\mathrm{x}$ Clarias gariepinus ). (http://www.mekarn.org/msc2003-

05/theses05/tram_p2.pdf , diakses pada tanggal: 10 September 2010).

[5] Edwards, C. A. (1985). Production of Feed Pro-tein from Animal Waste by Earthworms. Phil. Trans. R. Soc. Lond. B 310: 299-307

[6] M.C. Latumahina, M. Tapotubun, I.K. Savitri. 2007, Kandungan nutrisi Laor, Hibah Fundamental.

[7] [7] Poedjiadi Anna, F.M. Titin Supriyanti, 2009. Dasar- dasar Biokimia, Penerbit Universitas Indonesia. ISBN 974-456-308-0. 